\title{
ETNOGRAFANDO ASSALTOS CONTRA INSTITUIÇÕES FINANCEIRAS: A PUBLICAÇÃO DA PESQUISA, SEUS IMPASSES E DESDOBRAMENTOS
}

\author{
Jania Perla Diogénes de Aquino ${ }^{1}$
}

\section{Introdução}

Em minha tese de doutorado Príncipes e Castelos de Areia: performance $e$ liminaridade nos grandes roubos focalizei os assaltos contra instituições financeiras ${ }^{2} \mathrm{e}$ seus protagonistas. Por meio de um trabalho de campo com noves anos de duração em que recorri a diferentes fontes e ferramentas de pesquisa como notícias de jornais e entrevistas com policiais e delegados de Polícia, consegui uma considerável inserção no universo dos grandes roubos e pude me aproximar de assaltantes respeitados entre seus pares e tidos pela Polícia e os meios de comunicação de massa como "bandidos de alta periculosidade". Apesar de não ter realizado "observação participante" no sentido tradicional (e neste caso, certamente, não seria aconselhável), eu finalizei a tese convicta de ter realizado uma etnografia.

No início do trabalho de campo, os diálogos com praticantes de assaltos ocorreram no interior de uma prisão de segurança máxima, posteriormente tive oportunidade de fazer entrevistas, desenvolver conversas informais, conviver com pessoas foragidas da Polícia e em cumprimento do livramento condicional. Realizei entrevistas com quarenta e um assaltantes, consegui me aproximar e frequentar as residências de pelo menos onze destes homens, pude conversar em ocasiões variadas com seus familiares e amigos. Junto com estas pessoas participei de eventos sociais como aniversários, casamentos, festas de formatura e até mesmo de dois velórios.

Com base nesta experiência de pesquisa, problematizo as incertezas que permearam à elaboração da tese e sua defesa. Eu receava que o meu trabalho fosse alvo de suspeitas e até mesmo de perseguição por parte da Polícia. Afinal, até que ponto saber do paradeiro de criminosos fugitivos e ouvir relatos detalhados sobre ocorrências de assaltos cometidas, durante entrevistas realizadas, são práticas situadas nos domínios da legalidade? Também coloco em discussão uma inesperada interpretação da versão

\footnotetext{
${ }^{1}$ Universidade Federal do Ceará, Brasil.

2"Assaltos contra instituições financeiras" é uma categoria utilizada pelas Polícias Civis e Militares em vários estados do Brasil para designar roubos e furtos contra agências e postos bancários, roubos contra carros-fortes e empresas de guardas valores e arrombamentos de caixas eletrônicos.
} 
em livro da minha tese, por parte de um dos meus interlocutores de campo, que ficou decepcionado por suas narrativas e descrições não terem sido contempladas no texto. Tal ausência foi compreendida como desfeita. Ele não entendia como eu pude não dedicar pelo menos um dos capítulos do trabalho a sua trajetória no crime ou a um dos assaltos "cinematográficos" que ele organizou. Como conciliar expectativas dos nossos interlocutores de campo com demandas e critérios academicamente orientados que utilizamos para apresentar dados empíricos, elaborar nossa análise e modelar o texto? É possível? É viável? Por fim, discorro sobre um descuido ou negligência de minha parte, em relação a vida afetiva e conjugal das pessoas com quem desenvolvi diálogo em campo. Por um lado, empenhei atenção e esforço para que suas identidades fossem resguardadas em relação aos crimes que cometeram, utilizei nomes fictícios para pessoas e lugares, alterei datas de todos os eventos e ocorrências descritos no trabalho. Quis afastar possibilidades da Polícia ou a Justiça vir identificá-los. Por outro lado, não tive os mesmos cuidados em relação a dimensões "clandestinas" de suas vidas afetivas e conjugais. Descrevo em detalhes os namoros e casamentos que alguns dos meus interlocutores mantêm em simultaneidade com mulheres residentes em diferentes regiões do país. Caso suas companheiras venham a ler o livro, terão condições de identificar situações, pessoas e acontecimentos, concluindo que não são exclusivas na vida dos seus esposos e namorados. Tal descoberta decerto acarretaria tensões, conflitos ou rompimentos afetivos prejudiciais aos meus interlocutores.

\section{Tensão Pré-Defesa de Tese}

Em vias de finalizar o doutorado, eu tinha algumas daquelas preocupações que roubam a tranquilidade de pesquisadores às vésperas de suas defesas de tese: Será que a banca examinadora vai gostar do meu trabalho? Será que me sairei bem nas réplicas aos arguidores? Será que serei aprovada? A este receios se somavam outros e o "medo da banca" era menor que outros medos: com a apresentação pública da pesquisa e a disponibilização do texto na biblioteca e sitio eletrônico da universidade, havia o risco de eu me tornar alvo de suspeita ou mesmo de investigação ou acusação por parte da Polícia e da Justiça. Tendo em vista a condição ilegal de "fugitivo" em que se encontravam alguns dos meus interlocutores de campo havia a possibilidade da Polícia interpretar a tese como uma afronta ao seu trabalho e tentar criminalizar o meu 
empreendimento etnográfico. O que aconteceria? Eu seria indiciada como cúmplice?

Meu título de doutora seria invalidado? Muitas incertezas me rondavam. Em busca de "orientação" e apoio institucional, escrevi um e-mail amedrontado à Comissão de Ética da Associação Brasileira de Antropologia- ABA no dia 01/08/2009:

Caros membros da Comissão de Ética da ABA. Meu nome é Jania Perla Diógenes de Aquino, sou aluna do Programa de Pós Graduação de Antropologia Social da USP. No dia 4 de agosto do corrente ano estarei defendendo minha tese de doutorado intitulada "Príncipes e Castelos de Areia: Performance e Liminaridade nos Grandes Roubos". Neste trabalho, analiso a dimensão performática dos grandes roubos e das trajetórias de seus praticantes, a partir das perspectivas de análise de Erving Goffmam e Victor Turner. Estou escrevendo este e-mail para pedir orientação sobre possíveis desdobramentos e implicações éticas relacionados ao meu trabalho de campo, bem como consequências "jurídicas" que posso sofrer. Embora não seja filiada à $\mathrm{ABA}$, oriento-me pelo Código de Ética dos antropólogos ${ }^{3}$ disponível no site e, com base naquele texto, revelo no capítulo metodológico da minha tese que realizei entrevistas com assaltantes foragidos da Polícia.

Gostaria de obter alguma orientação da "comissão de ética" sobre este assunto, de me informar se o código de ética "abrange" antropólogos que ainda não estão filiados à ABA e qual a sua validade jurídica, no caso de antropólogos que realizaram entrevistas com praticantes de atividades criminais foragidos. Enfim, preciso de alguma orientação da "comissão de ética" e peço, antecipadamente, apoio. Caso seja importante, posso enviar a íntegra do meu trabalho para que seja analisado.

Na semana seguinte ao envio da mensagem, recebi uma comunicação assinada pela Secretaria Geral da ABA:

\footnotetext{
${ }^{3}$ Código de ética do Antropólogo (em vigência em 2009, período da correspondência transcrita) Constituem direitos dos antropólogos, enquanto pesquisadores: 1 . Direito ao pleno exercício da pesquisa, livre de qualquer tipo de censura no que diga respeito ao tema, à metodologia e ao objeto da investigação. 2. Direito de acesso às populações e às fontes com as quais o pesquisador precisa trabalhar. 3. Direito de preservar informações confidenciais. 4. Reconhecimento do direito de autoria, mesmo quando o trabalho constitua encomenda de Órgãos públicos ou privados e proteção contra a utilização sem a necessária citação. 5. O direito de autoria implica o direito de publicação e divulgação do resultado de seu trabalho. 6. Os direitos dos antropólogos devem estar subordinados aos direitos das populações que são objeto de pesquisa e têm como contrapartida as responsabilidades inerentes ao exercício da atividade científica. Constituem direitos das populações que são objeto de pesquisa a serem respeitados pelos antropólogos: 1. Direito de ser informadas sobre a natureza da pesquisa. 2. Direito de recusar-se a participar de uma pesquisa. 3. Direito de preservação de sua intimidade, de acordo com seus padrões culturais. 4. Garantia de que a colaboração prestada à investigação não seja utilizada com o intuito de prejudicar o grupo investigado. 5. Direito de acesso aos resultados da investigação. 6. Direito de autoria das populações sobre sua própria produção cultural. Constituem responsabilidades dos antropólogos: 1 . Oferecer informações objetivas sobre suas qualificações profissionais e a de seus colegas sempre que for necessário para o trabalho a ser executado. 2. Na elaboração do trabalho, não omitir informações relevantes, a não ser nos casos previstos anteriormente. 3. Realizar o trabalho dentro dos cânones de objetividade e rigor inerentes à prática científica. Fonte: Home Page da Associação Brasileira de Antropologia. www.abant.org.br. (C) 2009 Abant-ABA - todos os direitos reservados.
} 


\section{Ilma. Sra.}

Louvamos a preocupação de V. Sa. com os possíveis desdobramentos da tese "Príncipes e Castelos de Areia: Performance e Liminaridade nos Grandes Roubos" e, ainda, pelo fato de ter pautado a conduta de ter pautado a conduta de antropóloga pelo Código de Ética da Associação Brasileira de Antropologia (ABA).

Informamos que o Código é suficientemente claro sobre o direito à confidencialidade e que tal direito é inerente à prática da Antropologia e algumas outras profissões. Contudo a ação da ABA restringe-se aos seus associados. Sendo desejo de V. Sa. filiar-se estamos à disposição para acolher novos membros.

Caso venha a ocorrer algum problema e/ou quaisquer interferências indevidas de instituições judiciais ou policiais, cremos que seu/sua orientador (a) poderá manifestar-se via Programa ao qual V. Sa. encontra-se filiada remetendo o caso à ABA que, poderá, considerando a questão, manifestar-se, politicamente, sobre o assunto após análise.

Desejamos que a defesa de tese transcorra a contento e que os princípios democráticos do país estejam vivos e orientem as ações de todos.

Atenciosamente.

Fiquei parcialmente aliviada porque o documento parecia aprovar meu trabalho de campo e sugeria que se eu me filiasse à ABA teria um apoio mais consistente da instituição (claro que eu enviei todo o material necessário para filiação na mesma semana), todavia o texto não lançava luz sobre parte dos meus temores. Efetivamente, o Código de Ética da ABA é um documento que concede orientação institucional, amparo político e moral ao pesquisador, mas não implica em garantias jurídicas em relação ao exercício do seu trabalho e as consequências daí advindas. Associada à ABA ou não, eu continuaria vulnerável em relação ao meu maior receio: que um delegado de Polícia encontrasse semelhança entre o caso de assalto analisado no trabalho e alguma ocorrência em investigação, e viesse me convocar para prestar esclarecimentos, buscando me incriminar ou me pressionar a revelar os nomes dos praticantes de assaltos com quem mantive contato. Embora tenha utilizado nomes fictícios para os entrevistados, minha tese é abundante em detalhes de assaltos e de trajetórias de assaltantes, estas informações poderiam ser comparadas às que constam nos inquéritos de ocorrências investigadas nas delegacias.

Em relação a esta possibilidade, meus temores foram amenizados por instruções que recebi de Ana Lúcia Pastore Schritzmeyer ${ }^{4}$. Ela me orientou a inserir na tese notas que retirariam a utilidade jurídica das informações sobre ocorrências de assaltos e seus praticantes, presentes no texto. Desta feita, na página anterior à introdução da tese, enxertei o seguinte esclarecimento:

\footnotetext{
${ }^{4}$ Professora do Programa de Pós-Graduação em Antropologia Social-PPGAS da USP e Coordenadora do Núcleo de Antropologia do Direito-NADIR.
} 
Nota: Com o objetivo de preservar o anonimato dos meus interlocutores, na apresentação dos dados etnográficos, todas as alusões e referências a datas, locais, nomes próprios, nomes de empresas, estabelecimentos comerciais e quantias roubadas são fictícias.

Na página anterior ao segundo capítulo, onde analiso uma ocorrência de assalto em todas as suas etapas, esclareço que se trata de um evento ficcional:

Nota: O assalto contra a Secure Cash's Transport constitui em um evento ficcional, de modo que eventuais semelhanças entre esta operação criminal e ocorrências registradas por delegacias de Polícia não são de responsabilidade da autora.

Ao apresentar a ocorrência de assalto analisada como evento ficcional, o objetivo era destituir as informações ali contidas de validade para eventuais inquéritos ou processos judiciais. Na gramática jurídica associar algum evento ou narrativa à ficção lhe retira o estatuto de verdade. Por outro lado, na perspectiva antropológica tal condição não anula o valor de um dado de pesquisa. Ao comparar as descrições etnográficas e literárias, mesmo assinalando que uma delas é inventada e a outra anotada, Geertz (1985) afirma que ambas constituem modalidades de fictio, termo latino que, neste contexto, pode ser traduzido como fabricação. Nós antropólogos, ao nos apropriarmos de circunstâncias reais, a partir de uma dada perspectiva selecionamos personagens, eventos e sequências de eventos, assim fabricamos versões com recortes e enquadramentos específicos, nossas descrições de um modo ou de outro são também fabricadas. (Geertz, 1985). Em se tratando da minha tese, conforme mencionei acima, também foram modificados os nomes de pessoas, locais, empresas, as datas dos acontecimentos. Apesar da análise antropológica que desenvolvo ter partido de interlocuções com pessoas reais que se referia a outras pessoas e a fatos reais, o texto constitui uma narrativa ficcional.

A inserção de notas, alertando o leitor para a ficcionalidade de algumas informações contidas no trabalho parece ter sido acertada. Durante o desenvolvimento da pesquisa, fui percebendo que os assaltos contra instituições financeiras e seus protagonistas tendem a despertar curiosidades e um certo fascínio. Sempre que mencionava meu trabalho de campo para pessoas "de fora" ou "de dentro" da academia, era surpreendida com perguntas sobre detalhes das ocorrências e da vida pessoal dos chamados "assaltantes de banco", perguntavam-me também sobre as estratégias que acionei para conseguir contato direto com estes homens. Antes mesmo de apresentar a 
tese à banca examinadora, recebi e-mails e telefonemas de jornalistas, solicitando-me informações sobre o trabalho. Tais correspondências reforçaram minhas suposições de que profissionais da segurança pública e operadores do direito ficariam sabendo sobre minha pesquisa de campo junto a pessoas em situação de ilegalidade. Eu precisava encontrar maneiras de evitar complicações com a Polícia. Deste modo, apresentar a ocorrência trabalhada no texto e as identidades de seus participantes como ficcionais foi importante, serviu para amenizar a curiosidade dos futuros leitores da tese, não os incitando a descobrir onde ocorreu ou quem fez àquele assalto, ademais afastou a possibilidade do texto ser tomado como prova contra algum dos meus interlocutores em um eventual inquérito policial.

Analisando de modo retrospectivo, as preocupações que tive em 2009 aparecem como excessivas. Afinal apresentei a tese, publiquei o livro e não fui alvo de hostilidade, ameaça ou perseguição por parte da Polícia ou da Justiça. Um delegado da Polícia Civil do Ceará esclareceu-me que era remota a possibilidade de eu ser convocada para dar explicações sobre minha tese. Segundo ele, nas Polícias investigativas do Brasil, há pelo menos uma década, a quantidade de casos a ser investigados é muito maior do que o efetivo policial disponível. Sendo assim, somente diante de provas contundentes e inquestionáveis, um delegado de Polícia iria abandonar a sequência de ocorrências a ser investigadas e inquéritos em elaboração na seu distrito policial, para reabrir um caso cujas investigações já foram encerradas. Para ele, que leu o texto na íntegra, minha tese desperta suspeitas e incita a curiosidade, por abordar um assalto contra uma empresa de guarda valores em que uma quantia muito alta foi roubada, no entanto não fornece pistas ou provas capazes de justificar a reabertura de um caso já arquivado.

É verdade que minhas expectativas de ser procurada pela Polícia se concretizaram, mas suas demandas foram bastante diferentes das que eu temia. Depois de ter tomado conhecimento da pesquisa, por meio de uma entrevista que concedi a uma revista, um delegado da Polícia Federal, lotado em Mato Grosso, entrou em contato, inicialmente, parabenizando-me pela tese, depois passou enviar e-mails longos, nos quais apresentava detalhes de ocorrências por ele investigadas, queria saber minha opinião sobre quem seriam os suspeitos e as possibilidades de paradeiro dos mesmos. Pelo que entendi, ele buscava algum tipo de consultoria ou "orientação" para suas investigações. Posteriormente, um assessor administrativo da PF me propôs organizar 
uma apostila sobre "crimes contra instituições financeiras", este material seria distribuído para agentes e delegados em todo o Brasil. Não ousei recusar o convite, mas estou postergando-o até hoje.

Efetivamente, no Brasil não há registros de repressão ou perseguição explícita pela Polícia ou a Justiça direcionada a etnógrafos que pesquisam atividades ilegais e mantêm contato direto com seus praticantes ${ }^{5}$, seja porque não há efetivo policial para que delegados desprendam tempo investigando antropólogos ou porque "os princípios democráticos do país" estão vivos e orientando "as ações de todos", como deseja a Comissão de Ética da ABA no documento que me enviou. É estimulante verificar esta não incidência de ação formal repressiva a antropólogos por parte dos aparelhos de controle e repressão do Estado nacional. Entretanto, se o fizerem algum dia, a comunidade de cientistas sociais não dispõe de garantias ou ferramentas jurídicas para dissuadi-los, o apoio a um eventual colega em apuros desta natureza provavelmente seria político, a partir de moções repúdio, manifestações coletivas de protesto, artigos em jornais, circulação de posts em redes sociais, dentre outros instrumentos de mobilização. Não há um estatuto com peso jurídico, regulamentando situações como a que desenvolvi trabalho de campo. Não temos garantido o direito de etnografar atividades ilegais, nem de preservar a identidade dos nossos interlocutores de campo em dívida com a Justiça como têm, por exemplo, os jornalistas de manter suas fontes em sigilo. A rigor, realizei trabalho de campo na clandestinidade e estive vulnerável à tentativas de criminalização da minha etnografia ${ }^{6}$.

\footnotetext{
${ }^{5}$ É valido ressaltar que, nas décadas de 1980 e 1990, os trabalhos a respeito de práticas criminais e seus protagonistas, desenvolvidos com base em pesquisas etnográficas, eram escassos. Constituem notáveis exceções deste período, as pesquisas de Zaluar (1985), Barreira (1998) e Rafael (1998). A partir dos anos 2000, no entanto, uma quantidade maior de antropólogos se interessaram por estas temáticas e têm sido produzidas excelentes etnografias, focalizando atividades criminais e seus praticantes, destaco os trabalhos de Biondi (2010), Grillo (2013) e Marques (2015).

${ }^{6}$ Recentemente, nos Estados Unidos, ganhou notoriedade uma polêmica envolvendo a etnógrafa Alice Goffman, filha do célebre Erving Goffman (1982-1992). No apêndice metodológico de On the Run: fugitive life in an american city, a versão em livro da sua tese de doutorado, baseada em um trabalho de campo de campo com duração de seis anos, junto a jovens negros capturados pelo sistema de Justiça Criminal norte-americana, Alice conta sobre um amigo, apresentado como Chuck, um jovem negro que teria sido morto a tiros. Depois de informar sobre esta morte, a pesquisada narra uma situação em que dirige um carro acompanhada de um outro jovem interlocutor que porta uma arma, os dois estariam "caçando" o assassino de Chuck. Depois que seu trabalho foi publicado e ganhou destaque na academia e na mídia norte-americana, por conta deste episódio, Alice vem sendo acusada por juristas de ter cometido um crime no desenvolvimento de sua pesquisa de campo. Tal argumento tem sido mobilizado, em artigos de jornais e comentários em revistas especializadas, para criminalizar e comprometer a credibilidade de sua etnografia.
} 
A suspeição e o medo que me acompanharam de modo intenso nas semanas anteriores e posteriores à defesa da tese, que ora explicito, também estão relacionados a experiências, sensações e cuidados presentes no cotidiano meus interlocutores de campo, sobretudo quando vivenciam a condição de fugitivos, o receio de serem localizados, presos e até alvo de disparos pela Polícia se impõe a suas rotinas, orientam ações e tomadas de decisões. Depois de uma investida etnográfica que envolveu aproximação e convívio com interlocutores praticantes de assaltos e vários meses refletindo e sistematizando em escrita minhas análises e aferições sobre o universo dos grandes roubos, acabei por experimentar uma condição muito próxima ao que FavretSaada (2005) chamou de "ser afetado". "Ser afetado" não se confunde com afetividades, tampouco com "observação participante" - apesar de não as excluir. Tendo realizado sua pesquisa no Bocage francês sobre feitiçaria, a autora apresenta tal condição como um dispositivo metodológico e existencial que envolve a capacidade do pesquisador de se colocar em certas posições que o permitam determinadas experiências. "Ser afetado" requer a exposição do estudioso às forças e intensidades que atuam sobre seus interlocutores. Mesmo jamais tendo presenciado ou participado de um assalto contra instituição financeira, nem tendo sido identificada como tal ou vivenciado a tensão de ser alguém "procurado pela Polícia", mesmo assim me senti "afetada" pelas dinâmicas e lógicas norteadoras deste universo de práticas e as singularidades de um tipo de rotina "fora da lei", que esta atividade ilegal impõe aos seus praticantes. Inteirando-me de excessos, riscos e contrastes que tal alternativa de vida desencadeia, foi possível um tipo de apreensão ou experimento de suas intensidades, vibrações e frequências. Provavelmente, por estar absorvida intelectual e sensorialmente pelo universo dos grandes roubos e o cotidiano de seus protagonistas, eu conseguia com facilidade visualizar-me alvo de desconfiança e investigação policial, depois que a tese fosse defendida.

\section{Dilemas na reciprocidade entre observador e observado e a reflexividade na pesquisa etnográfica}

Conforme tenho mencionado, no período em que escrevia a tese temia revelar involuntariamente algum dado ou informação que pudesse identificar meus interlocutores de campo no texto ou prejudicá-los diante da Polícia e da Justiça, tomei 
todos os cuidados possíveis para não fazê-lo. Estive empenhada em não lhes causar nenhum tipo de dano, sobretudo prisão ou morte. Mas se o trabalho não lhes acarretou prejuízos desta natureza veio deslanchar outro tipo de insatisfações.

Uma das pessoas com a qual realizei entrevistas e conquistei considerável proximidade surpreendeu-me com seu descontentamento ante a versão em livro da minha tese, por motivos bastante inusitadas. João Marcos tem 31 anos, eu o conheci em 2003 e o reencontrei várias vezes, desde então. Conforme pude perceber durante o trabalho de campo, ele se vê e é visto entre outros "assaltantes de banco" como competente, "sortudo" e "juntador de dinheiro". Durante o período de nove anos em que participou de assaltos, acumulou altas quantias e as investiu em variadas modalidades de negócios legais. João ficou magoado com a completa ausência de suas falas ou referências aos seus "feitos" no texto da minha tese. O modo como apresentei e analisei os dados obtidos no campo acabou não contemplando suas narrativas ou descrições de assaltos que ele organizou. Para agravar seu descontentamento, em um dos capítulos do trabalho, apresento um assalto do qual participou Auricélio, um outro assaltante, meu interlocutor de campo, com quem João Marcos já se desentendeu. Além de uma exposição detalhada de um assalto do qual participou Auricélio, destaco variadas situações e eventos "marcantes" em sua trajetória. Tendo me concedido entrevistas e contado detalhes de operações das quais participou, João se sentiu preterido e viu as minhas escolhas de eventos e personagens apresentados no texto como indícios de predileções. Ele me acusou de apresentar Auricélio e Lúcio (outro dos participantes do assalto analisado no trabalho) como "os melhores assaltantes do Brasil". Embora eu não afirme isto em nenhum trecho da tese, reconheço que esta é uma interpretação possível porque estes personagens ganham considerável destaque em pelo menos três capítulos no texto. Em parte, compreendi seu desagrado, pois ele tinha me dito algumas vezes o quanto achava Auricélio "folgado" e que Lúcio é arrogante e convencido. Dar preferência as narrativas e trajetórias de seus colegas, foi como se eu o desprezasse. Meu livro afrontava sua vaidade.

As impressões de João Marcos a meu respeito pioraram quando ele soube de uma estória disseminada por Auricélio (em tom de brincadeira) de que eu estava escrevendo um livro sobre sua vida. Isto o fez concluir que Auricélio havia me pagado para ser sua biógrafa. Quando me telefonou para manifestar seu desagrado, João Marcos estava convicto de que eu tinha recebido dinheiro de Auricélio e Lúcio para privilegiar seus 
assaltos e suas narrativas biográficas na tese. Ao lançar esta afirmativa acusatória, ele indagou porque eu não lhe tinha feito a mesma proposta, já que ele dispunha de quantias maiores ou igual aos dois colegas e enfatizou que sua vida tinha "estória suficiente para escrever vinte livros". Foi necessária uma certa persistência de minha parte para explicá-lo sobre meus critérios e motivações na escolha do evento e trechos de trajetórias analisados na tese.

Já sem muitas esperanças de reconquistar sua confiança, resolvi procurar João Marcos para avisá-lo que eu tinha abordado detalhes de sua vida afetiva em um texto ${ }^{7}$ apresentado no Internacional Congress of Americanists de 2012, em Viena, contei que as coordenadoras do Simpósio Temático gostaram da pesquisa e me convidaram para escrever um capítulo de uma coletânea, que seria publicada pela editora do Centro de Investigacioanes y estudios superiores en Antropologia Social-CIESAS localizada em Cidade do México. Para minha surpresa e sorte, ele fez uma leitura peculiar de todas estas informações e se mostrou muito satisfeito. Poucos dias depois de nossa conversa, soube por outros interlocutores de campo que João entrou em contato com dezenas de pessoas para contar que eu tinha sido convidada para dar palestras nas universidades da Europa sobre a vida dele e que iria lançar um livro pela "maior editora do México", tendo como tema a sua biografia. Ao difundir esta estória, ele acrescentava que havia muitas chances do livro sobre sua vida se transformar em filme. É interessante observar o modo como meu interlocutor selecionou alguns detalhes do que lhe contei, efetuando torções nas informações, de modo a apresentá-las como motivo de auto propaganda. $\mathrm{Na}$ versão de João Marcos, sua trajetória é elevada a um roteiro que desperta o interesse dos círculos universitários europeus e do mercado editorial mexicano, podendo vir a se tornar roteiro de um filme.

Além de ter me impressionado sobre o quanto a vaidade infantiliza e faz parecer pouco inteligentes pessoas muito inteligentes, a reação de João Marcos tem relevância epistemológica e expõe algumas tensões ou "efeitos colaterais" da relação observadorobservado ensejada pela etnografia. Ficou evidente que minhas incursões em campo gerou expectativas e competição entre as pessoas com quem desenvolvi diálogo, o interesse que direcionei às narrativas de cada um deles acabou se tornando motivo de disputa. Embora soubesse que meus interlocutores de campo iam querer ler a tese, não

\footnotetext{
7"Amor Bandido": "performances" y "disfarces" en la vida afectiva y familiar de "asaltantes de banco" en Brasil", este foi o título do texto apresentado no Simpósio Temático 820-Matrimônios: intereses, acuerdos, afectos.
} 
supus que minhas escolhas sobre descrições de eventos e trechos de entrevistas a serem expostos no texto iriam render "capital simbólico" a alguns deles e, por outro lado, atingir vaidades e sentimentos dos que não aparecessem como personagens de relevância.

$\mathrm{Na}$ verdade não é raro que pessoas e coletivos observados esbocem demandas ou expectativas direcionadas ao antropólogo. Há variados exemplos de como as relações que se desenvolvem no trabalho de campo acabam por transbordá-lo. Em se tratando das religiões afro-brasileiras, são recorrentes as conversões dos seus estudiosos e as situações em que os mesmos são mobilizados como ícones de relevância e prestígio de um determinado terreiro ou pai de santo nas disputas simbólicas com outros terreiros ou mesmo em situações de conflitos envolvendo outras relegiões (Silva, 2004). Além deste tipo de adesões peremptórias, há outras maneiras mais circunstanciais de o pesquisador atender expectativas ou demandas que lhes são colocadas por seus interlocutores, Zaluar (1985, 1995) conta que em sua etnografia realizada em Cidade de Deus, bairro localizado na periferia do Rio de Janeiro, os moradores do lugar mobilizavam sua presença com orgulho, diante de políticos e eventuais visitantes "ilustres". Ressaltar que havia uma pesquisadora "da universidade" interessada em seus modos de vida era uma maneira de elucidar a relevância social do bairro.

No caso da minha pesquisa, durante o desenvolvimento do trabalho de campo não era evidente que houvesse alguma apropriação ou disputa simbólica desta natureza por parte dos "meus nativos". Se o que os coneta e os leva a compor agrupamentos circunstanciais que a Polícia denomina quadrilha é a intenção de realizar grandes assaltos, considerando que tais ocorrências constituem atividades criminais, e que figuram como uma dimensão clandestina de suas vidas, sempre supus que tal prática fosse incompatível com bandeiras ou causas que envolvem discursos e reivindicações coletivas ou de caráter público. Se eu fosse advogada, teria sido razoável prever que eles criariam expectativas ou esboçariam demandas, incorporando-me em seus círculos de reciprocidade. Meus saberes de antropóloga pesquisadora parecia não lhes ter serventia, nem potencial para lhes conferir ganhos materiais ou simbólicos.

Este anseio de João Marcos e, certamente, de outros assaltantes por figurar como personagens nos meus textos, e de contar para as pessoas dos seus círculos de amizade que há uma pesquisadora "escrevendo livros" sobre suas vidas, chama a atenção para demandas, leituras e interpretações diferentes das acadêmicas, acerca do trabalho de 
campo e do conhecimento antropológico. Ao produzir descrições e análises, buscamos atender a exigências e critérios de validação dos nossos trabalhos, instituídos na academia. Por sua vez, as pessoas e coletivos observados se orientam por referenciais e expectativas de outra natureza para apreciar nossas etnografias e as maneiras como estão sendo representados nestes textos. Este é um dos mais importantes desafios intelectuais e morais que se colocam aos etnógrafos da atualidade. Passar pelo crivo dos nossos interlocutores, nem sempre é fácil ou possível.

Tendo em mente a diversidade de públicos e critérios, a partir dos quais têm sido avaliadas etnografias no mundo pós-colonial, Geertz (2002) apresenta algumas indagações cujas respostas não são evidentes, simples ou definitivas: Quem deve ser convencido hoje em dia: os africanistas ou os africanos? Os americanistas ou os índios norte-americanos? Os nipologistas ou os japoneses? E convencidos de que: da exatidão dos fatos? Do alcance teórico? Da apreensão imaginativa? Da profundeza moral? (Geertz, 2002: 174).

Atualmente se colocam ao antropólogo dificuldades em delimitar os padrões e os objetivos da sua retórica. Há demandas e expectativas que se esboçam sem que ele possa prever, nem controlar os desdobramentos. Em se tratando das queixas que João Marcos direcionou ao meu trabalho, servem para elucidar não só os limites em discernir os interesses em jogo, mas também o sentido dado à interpretação do texto etnográfico, bem como as escolhas, presenças e ausências de personagens e eventos no texto. Ao tentar esboçar um panorama das modificações nos modos "tradicionais" de produzir etnografias provocadas pelo que costuma ser chamado de "tendência pós-moderna na Antropologia", George Marcus (1994) elucida a impossibilidade de um "sentido fixo" em relação à interpretação e apropriação dos textos etnográficos depois que se tornam públicos. Para o autor:

A premissa pós-moderna de que não há possibilidade de um sentido fixo, final, monologicamente dominante radicalizou as críticas dentro da antropologia, de suas formas de representação, ao desafiaras autoridades em que elas se baseavam. Ela também minou a prática de um tipo de interpretação na qual um sentido fixo dominante pode ser deduzido (Marcus, 1994: 13-14).

As afirmativas de Marcus (1994) são relevantes para refletirmos sobre os contextos a partir dos quais temos produzido representações "dos outros" e para a variedade e complexidade em seus interesses, interpretações e expectativas que podem 
ser esboçadas aos nossos textos. Neste cenário, a reflexividade tem sido cada vez mais característica da relação observador-observado.

Com o fim da divisão do mundo entre colônias e metrópoles, e com a difusão das tecnologias de informação, a acessibilidade ao conhecimento antropológico foi expandida e a reflexividade que é intrínseca aos "encontros" entre diferentes promovidos pela etnografia foi intensificada. A posição de analista que experimentamos também pode ser assumida pelas pessoas e coletivos com quais desenvolvemos diálogo. De acordo com Wagner (2011) nossa condição de observador, mais do que reflexiva, é genuinamente reversível e partilhada com o observado.

Um fenômeno marcante na disciplina antropológica nas últimas décadas é a disseminação do que Strathern (1986) chama de "antropologia feita em casa" ou "autoantropologia", referindo-se a pesquisas em que o antropólogo aborda pessoas e coletivos inseridos em sua própria sociedade. Com a dissolução do mundo colonial e a emancipação dos chamados "países de terceiro mundo", depois de ter passado um período de crise em decorrência da extinção dos "nativos" tradicionais que povoavam as etnografias clássicas, as antropologias "metropolitanas" reinventam-se incorporando aos seus interesses de pesquisa análises de coletivos e fenômenos situados na própria sociedade "do observador". Quando "nativos" integram a mesma sociedade que o antropólogo, a reflexividade tende a se impor, alargando possibilidades dialógicas e de simetrização na relação observador-observado ${ }^{8}$.

Em se tratando do meu empreendimento etnográfico junto a praticantes de assaltos contra instituições financeiras, embora haja entre nós um "grande divisor" (Goldman \& Stolze, 1999) instituído pelos regimes de moralidades dominantes que demarca e estigmatiza os que habitam um suposto "mundo do crime", a pesquisa pode ser considerada uma experiência de "antropologia feita em casa", já que habito o mesmo país dos meus interlocutores, falamos a mesma língua vernácula, estamos sujeitos aos

\footnotetext{
${ }^{8} \mathrm{O}$ Brasil, na condição de uma ex-colônia com dimensões continentais e marcado por diversidades e "fricção interétnica" (Cardoso de Oliveira, 1963), enseja uma tradição antropológica, cujos coletivos etnografados em sua quase totalidade estão situados no interior das fronteiras nacionais, sendo marcante inclusive em alguns trabalhos "pioneiros" o afã por elucidar "nossa identidade", tida como "enigmática" e caracterizada pelo fenômeno da miscigenação e do intenso contato intercultural. Entre os antropólogos brasileiros, quando classificamos as etnografias por suas temáticas, costumamos considerar "etnologia" pesquisas sobre comunidades indígenas e quilombolas, denominamos "antropologia rural" os trabalhos sobre habitantes da zona rural do país e "antropologia urbana" os estudos sobre fenômenos e coletivos das grandes cidades (Roberto da Mata, 1992). A dialogia e reflexividade tem sido marcantes na tradição etnográfica nacional, sendo recorrente nos trabalhos um fascínio entusiasta e generoso em relação a alteridade.
} 
mesmos códigos jurídicos e a outros sistemas simbólicos de dimensões intelectuais e morais. Ao finalizar o trabalho não parecia possível prever as interpretações e reações que despertaria nos sujeitos da pesquisa. Ciente de que a maior parte deles utilizam cotidianamente a internet, com certeza acessariam o conteúdo da tese e posteriormente do livro. Inevitavelmente eu seria confrontada com suas "leituras". Esperava por mal entendidos e queixas, mas me equivoquei ao supor as nuances da temática abordada que desagradariam meus interlocutores. Imaginei que poderiam se sentir insultados por não serem apresentados como "heróis" no trabalho ou por minha análise não atribuir positividade moral aos assaltos contra instituições financeiras. Mas, como visto, as expectativas de uma parte deles estavam relacionadas à presença de seus relatos e menções aos seus "feitos" no livro. Queriam mostrar a outros assaltantes suas falas e narrativas, ouvi expressões como as seguintes: "isto aqui quem falou foi eu"; "essa história quem contou a ela foi o Fernando"; "eu também tava nessa fita". A forma como alguns assaltantes leem e releem o livro é peculiar, não se detêm nos trechos em que dialogo com a bibliografia em ciências sociais, tampouco nas discussões metodológicas que desenvolvo, concentram o interesse nas partes em que descrevo ocorrências ou transcrevo falas das pessoas que concederam entrevistas, identificam suas falas com rapidez e tentam desvendar quem proferiu os demais relatos e narrativas apresentadas, pressionam-me para confirmar ou negar suas suposições: "isso aqui quem falou foi o Fabrício não foi?"; "Esse Maurício é o Ricardo não é?"; "Pelas palavras desse aqui, parece com o jeito que o Pedro fala, esse 'meu' pra lá, 'meu' pra cá é coisa de paulista, esse cara é Pedro, certeza".

Entendo que o anseio de João Marcos por figurar como personagem no meu texto e de contar para as pessoas dos seu círculos de amizade que há uma pesquisadora "escrevendo livros" sobre ele, de algum modo, expressa o desejo de que se tornem públicas outras narravas sobre sua vida, além das notícias nas páginas policiais onde é designado por termos como "meliante" e "elemento". Fui persistente ao tentar me explicar e amenizar seu descontentamento em relação ao meu livro, não o fiz por acreditar que minha vida estaria em perigo caso ele continuasse aborrecido. Acredito que um trabalho de campo não é completo se as relações entre o pesquisador e os sujeitos de sua pesquisa não forem significadas positivamente por ambos, acho que a etnografia deixa de ser um encontro intercultural com o efeito de "alargar o discurso humano", como afirma Geertz (1985), quando ocorre de nossos interlocutores se 
sentirem prejudicados ou enganados ante os resultados das nossas pesquisas. Embora não tivesse prometido que iria transcrever suas falas e apresentar detalhes de sua biografia na minha tese, durante alguns meses me senti desconfortável por frustrar suas expectativas. Ciente desta desatenção involuntária, conforme assinalei anteriormente, tratei de contemplar alguns de seus assaltos e parte de sua trajetória em um texto, felizmente tal demonstração de reverência, apesar de singela, foi suficiente para deixálo envaidecido. Sem pretender romantizar ou colocar em um santuário moral e epistêmico a relação observador-observado, creio que o etnógrafo, sempre que necessário, deve se empenhar em reverter os efeitos perversos das trocas assimétricas ensejadas pelo trabalho de campo, preservando em ambos os lados a crença de que houve diálogo.

\section{O que escapa às "boas intenções" do pesquisador: inconfidências não intencionais no texto}

Somente dois anos depois que o livro foi publicado percebi uma espécie de inconfidência que cometi em relação à vida afetiva de alguns praticantes de assaltos contra instituições financeiras. Atentei para este detalhe durante um diálogo com um dos meus interlocutores de campo por correspondência eletrônica, utilizando o programa Windows Live Mensenger. De modo descontraído, André me fez perceber que se a esposa de um dos meus principais interlocutores viesse a ler o texto, haveria desentendimentos e brigas entre o casal. Transcrevo um trecho de nossa conversa no dia 12 de novembro de 2012.

A- sabia que a mulher do Auricélio vai dar as contas dele por sua culpa?

J- Como?

A- seu livro

A- se a riquinha descobrir que ele tem mais 4

A- a casa cai kkkkkkk e eu quero ver kkkkkk

$\mathrm{J}$ - vixe!

J- mas eu mudo o nome de todo mundo, e ele não tem mais 4, ele tem ela e mais 3 
A- ele espalhou pra Deus e todo que vc tava fazendo um livro da vida dele

\section{A-kkkkkkkkkkkkk}

A- o cara se ferrou!!!

J- não! ele falava brincando, ninguém acreditava que o livro era sobre a vida dele

A- se alguma mulher de ladrão ler sua obra o casamento vai pro espaço,

A- vc dedura todo mundo kkkkkkk

$J$ - terrorista $v c !$

J- mas o pior é que foi mesmo, eu só pensei na Polícia, não pensei nas mulheres lendo o livro

A- mas mulher tb eh polícia, vai dizer $q$ n sabe kkkk

J- mulher do Auricélio, ela pode até suspeitar que é ele, mas prova ela nunca vai ter, eu não falo o nome dele, tem muita coisa ali que ela pode perceber, mas prova mesmo ela não vai ter

A- hahahha até parece,

A- mulher e Polícia não precisa de prova pra cair em cima e condenar

A- vc queima o filme de todo mundo kkkkk chora vai

J- eu não ferro ninguém, você tá é doido rss

A- essa menina é dedo duro, fala que a gente tem mil mulheres

A- que arruma uma namorada cada cidade, ferrou geral kkkkk

J- e eu menti?rss Não falo que vocês tem mil, falo que muitos tem umas três ou quatro.

A- exagerou, por exemplo EU, não corro atrás de todas as mulheres

J- Corre não? Então nas entrevistas vc mentiu, foi?

A- Eu não corro atrás de todas, só das bonitas kkkkkkkk

J- Ahhhh mas eu falo isso

A- Chamou a gente de galinha pra todo mundo sabe kkkkkk

J- O pior é que foi, eu não chamei, mas mostrei que são rsss isso não foi bacana.

J- Pode ter um monte de casamento desfeito.

J- Esse assunto é serio.

J- Fala sério! Vc acha de que a mulherada do pessoal vai ler?

A- Pra valer, acho difícil, a minha nunca vai ler

J-Tomara!

A- Relaxa, vc enche a bola de todo mundo, diz que o pessoal todo tem dinheiro, eles vão gostar 
A- você diz que cada um tem um harém

A- isso ai eh bom sabia?

A- Atrai mais gatinhas

J- atrai nada rss

A-se vc tá bem acompanhado sempre atrai mais uma

A-mais uma

A- mais uma

J- rsssss

J- é a vida né... as águas correm para os rios rsss

A- pode crer $k k k k k k k k k k k k$

A- se a gatinhas da sua faculdade se interessar, você fala de mim primeiro, certo? kkkk

A- diz que eи sou o mais bonito

A- com mais dinheiro e tal

J- hahahhaha ah coitado! Vá contando com isso rsss

A- ai vc dar meu telefone para as gatinhas da UFC

$\mathrm{J}$ - pode contar com isso rsss

Empenhada em evitar que a pesquisa trouxesse complicações com a Polícia às pessoas com quem desenvolvi diálogo, acabei me esquecendo de ocultar ou omitir a condição poligâmica, um tanto quanto secreta, em suas vidas afetivas e conjugais. Considerando que estes homens não desafiam apenas o Código Penal, mas também as regras da monogamia, estabelecidas moral e juridicamente no ocidente, ter apresentado descrições detalhadas e análises dos namoros e casamentos que alguns dos meus interlocutores mantinham em simultaneidade poderia lhes causar brigas e rompimentos em suas relações amorosas.

É recorrente que os chamados "assaltantes de banco" mantenham duas ou três companheiras, residindo em cidade diferentes e que estas mulheres, por longos períodos, acreditem serem as únicas na vida afetiva de seus namorados ou esposos. Em larga medida, as maneiras como estes homens conduzem suas relações amorosas está associada a demandas da condição de praticantes de assalto, uma atividade ilegal, violenta, alvo de repressão policial, que envolve contínuos deslocamentos e requer 
mudanças de local de residência em curtos intervalos de tempo. Seus arranjos afetivos e familiares ganham intelegibilidade quando observamos o cotidiano destes "profissionais do crime", marcado por incertezas e mudanças repentinas, onde a aquisição de altas quantias não os isenta do risco de serem presos ou mortos em confrontos armados com a Polícia ou com outros assaltantes.

No cotidiano de quem participa de assaltos de grande porte são recorrentes as viagens para outras cidades e regiões do país não só para fugir da Polícia, mas também para escolher os alvos de suas investidas, elaborar planos e efetuar as ações armadas. Uma das características mais ressaltadas por delegados de Polícia nas quadrilhas que se formam para realizar assaltos contra instituições financeiras no Brasil é a sua composição interestadual, são coletivos que aglutinam assaltantes residentes em diferentes estados e regiões do país, o que dificulta o trabalho de identificá-los e prendêlos. Até que sejam localizados pela Polícia, não costumam revelar o envolvimento em atividade ilegal aos seus familiares. Esposas e namoradas quase sempre tomam conhecimento da "vida secreta" do companheiro em decorrência de prisões súbitas ou pela veiculação de suas fotografias ou retrato falado em jornais impressos e programas policiais de TV.

Quando são identificados e passam a ser procurados pela Polícia de um determinado estado ou cidade, praticantes de assaltos tratam de mudar o local de residência. As recorrentes mudanças de endereço são acompanhadas pela adoção de codinomes e documentos falsificados. Ao chegar em determinada cidade com a intenção de fixar residência, elaboram enredos fictícios para suas vidas. Além de nomes falsos, fornecem informações inverídicas sobre procedência e descendência familiar. Na condição de fugitivos da Polícia, apresentam versões fictícias de suas trajetórias e das "profissões" que exercem. Quando se certificam de que não há riscos imediatos de serem identificados, tratam de adquirir bens e construir relações com moradores da cidade. Compram imóveis, abrem negócios, arrumam namoradas, costumam se aproximar de famílias de classe média e alta com perfil similar a do personagem que estão desempenhando.

O envolvimento afetivo e conjugal com duas, três, quatro e até cinco mulheres que residem em cidades diferentes, assim como o uso de nomes fictícios e documentos falsificados é bastante difundido entre praticantes de assaltos contra instituições financeiras. A cada personagem, corresponde uma companheira, e um conjunto de bens 
e investimentos na cidade onde ela reside. Além de funcionar como um modo de ocultar as quantias que roubam, a manutenção de várias unidades familiares e econômicas em diferentes regiões do país é uma salvaguarda no cotidiano destes criminosos foragidos, que estrategicamente dispõem de múltiplos "esconderijos", entre os quais se revezam de modo sagaz.

Estes vínculos amorosos variados e mantidos em simultaneidade, que caracterizam a condição de poligamia "velada" entre praticantes de assaltos, costumam se manter por longos períodos sem grandes transtornos. Um mesmo homem consegue dividir a atenção e o afeto entre suas companheiras por vários meses e anos. O segredo é fundamental para que estes enlaces perdurem. Conflitos e rompimentos quando ocorrem, geralmente, têm relações com suas prisões repentinas. É somente nestas ocasiões, ao se depararem com outras esposas e namoradas, que algumas mulheres descobrem a "infidelidade" do parceiro. Na condição de presidiários, torna-se mais difícil manter em segredo os múltiplos vínculos amorosos que, até então, movimentavam suas vidas afetivas fora dos muros penitenciários. Se antes, o homem ia ao encontro de suas companheiras, quando está preso, elas é que são solicitadas a virem até ele.

Tenho observado que o período imediatamente posterior a descoberta de que o companheiro pratica atividades ilegais é vivenciado por suas mulheres com perplexidade, desilusão e vergonha diante de familiares e amigos. Todavia esta notícia que abala, raramente chega a destruir um relacionamento. $\mathrm{O}$ que efetivamente arrisca os vínculos de praticantes de assaltos com suas companheiras é a descoberta por estas de que não têm exclusividade na vida amorosa do cônjuge. Tal informação costuma provocar mágoas e sofrimentos que, segundo algumas mulheres com quem conversei, não são esquecidos nem mesmo quando o relacionamento é reatado. Acompanhei alguns casos em que esposas e namoradas tomaram conhecimento de outros relacionamentos de seus companheiros e foram situações conflituosas, vivenciadas com choro e ameaças mútuas entre as mulheres envolvidas. Por outro lado, também presenciei circunstâncias que mulheres descobriram que seus esposos ganhavam a vida praticando assaltos, que constitui outra descoberta impactante e desoladora. Embora emoções não sejam mensuráveis em uma escala, nos episódios envolvendo traição conjugal, a dor pareceu mais intensa e duradoura do que a decepção de saber que o companheiro comete crimes violentos. 
Considerando que estes homens transgridem as regras da monogamia e que suas vidas afetivas e conjugais são marcadas pela clandestinidade e muitos segredos, a pesquisadora poderia ter sido mais cuidadosa ao abordar peculiaridades de suas vidas amorosas. Conforme tenho explicitado, se ocorrer de uma companheira de um eventual "assaltante de banco" ler minha tese, haverá desconfiança em relação ao parceiro. Além das namoradas e esposas de Auricélio e Lúcio (os dois praticantes de assaltos cujas trajetórias analiso no trabalho), meu texto tem o efeito de construir uma imagem negativa (embora verdadeira) destes homens, diante de eventuais pretendentes que tenham expectativa de relações monogâmicas e exclusividade conjugal. Como disse André, eu "queimei o filme" dos meus interlocutores e, indiretamente, de todos os que participam de assaltos contra instituições financeiras perante o sexo feminino. Alguns praticantes de assaltos com quem conversei sobre este tema o levaram em tom de brincadeira, mas se trata de um assunto serio, pois a dimensão afetiva e os vínculos conjugais, como visto, são centrais em suas vidas.

Embora as informações que se tornam públicas por meio de páginas policiais a respeito de homens que participam de assaltos contra instituições financeiras quase sempre estejam relacionadas ao grau de violência dos crimes que cometem, dando a impressão de que são pessoas que dedicam suas vidas exclusivamente às atividades criminais, durante o trabalho de campo pude perceber que os vínculos afetivos com suas companheiras e outros familiares, e as obrigações daí resultantes, são tidos como muito relevantes e movimentam variadas dimensões de suas vidas. Além de assumir e administrar bens e negócios legais de seus esposos e namorados, adquiridos com dinheiro oriundo de assaltos, as mulheres lhes aguçam a vaidade. A maior parte das que conheci correspondiam aos padrões de beleza dominantes (magras, tinham o corpo modelado por curvas, glúteos proeminentes e cabelos longos), eram da classe média e tinham formação universitária concluída ou em andamento.

Cheguei a ouvir de alguns entrevistados que a motivação para ingressar nas atividades ilegais foi o anseio de serem desejados e vistos como "bons partidos" pelo "tipo" de mulher que os interessavam. Vejamos trechos da fala de um deles:

Se eu disser pra você que eu não me sinto feliz com tudo o que eu conquistei eu tou mentindo, andar de "Pagero", ter casa grande, ter outros apartamentos é muito bom, quem não ia gostar? Mas bom de verdade é ter a mulher que eu quero, ter uma mulher bonita, decente, que faz bonito em todo lugar, todo mundo te olha e sente inveja. Quando eu não roubava não era assim não, agora eu tenho quem eu quiser. 
Hoje eu tenho três, todas gatas, de família boa, as três são formadas. E eu dou tudo do bom e do melhor pra elas.

Mesmo não desempenhando funções relevantes na elaboração de um assalto, tais mulheres assumem protagonismo na biografia de praticantes de grandes roubos, além de lhes auxiliar em assuntos práticos ou operacionais, funcionam como um suporte subjetivo, fundamental para a autoestima destes homens.

Em nossa conversa pelo Windows Live Mensenger acima transcrita, André afirma que há um "um lado bom" em tornarem públicos os múltiplos laços afetivos e conjugais mantidos por meus interlocutores de campo, argumentando que tal informação ao invés de lhes prejudicar, irá lhes atrair "mais gatinhas". Não acho provável que a difusão desta informação lhes traga ganho nas conquistas amorosas. Conforme observei durante o trabalho de campo, o segredo em relação à existência de outras mulheres é fundamental para que um novo relacionamento seja concretizado. Nas primeiras semanas de conquista, meus interlocutores, via de regra, buscam fazer com que suas "escolhidas" se sintam únicas, tratam de impressiona-las com joias, chegando mesmo a presenteá-las com carros e imóveis. Nestes períodos iniciais, não seria nada conveniente que a fidelidade do pretendente fosse colocada em suspeição. Deste modo, ao difundir na tese a imagem de praticantes de grandes roubos como "mulherengos" ou "galinhas", posso ter lhes prejudicado seriamente em futuras investidas amorosas.

Não estou esquecendo do potencial de mentir convincentemente e de reverter situações difíceis por estes homens. Acompanhei alguns deles superar sérias rupturas, conseguindo reverter desconfianças e decisões de suas companheiras de interromper o vínculo conjugal. Foi surpreendente, observar mulheres indignadas e que pareciam decididas a terminarem a relação, serem convencidas a perdoar o cônjuge, mostrando-se novamente carinhosas e dedicadas. Mas a lábia e capacidade de persuasão dos meus interlocutores não amenizam a inconfidência contida do meu livro. Mesmo que tal descuido não venha ocasionar rompimentos ou outros tipos de prejuízos às vidas afetivas e conjugais dos sujeitos da pesquisa, ter direcionado cuidados e agenciamentos metodológicos para assegurar o anonimato de meus interlocutores exclusivamente em relação as suas transgressões do Código Penal, esquecendo-me ou não considerando relevante a clandestinidade em suas relações amorosas, acabou por denunciar que, efetivamente minha forma de concebê-los não diferenciava muito da imagem difundida pela imprensa policial, que os apresenta como "bandidos de alta periculosidade". 
Quis abordar este "descuido" na escrita da minha tese para dar ênfase à armadilha epistemológica aí exposta. Naquele trabalho, busquei mostrar que além da condição de bandido violento, era possível apreender praticantes de atividade ilegais por outras perspectivas e enquadramentos. Queria ir além da identidade estigmatizante e reducionista de "bandido" e elucidar a complexidade de suas trajetórias. A intenção era produzir "ciência social do observado" tal qual a concebe Levi-Strauss (2008). Contrastando Sociologia e Antropologia, o mestre francês afirma que a Sociologia se esforça em fazer a ciência social do observador, sendo com este estreitamente solidária e mesmo quando toma por objeto uma sociedade diferente, esta disciplina, assumiria "o ponto de vista da sociedade do observador". A Antropologia, por outro lado, adotando "o ponto de vista do nativo" ou de um sistema de referência fundado na experiência etnográfica se caracterizaria pelo esforço em elaborar uma "ciência social do observado" (Lévi-Strauss, 2008).

Ao considerar que poderia prejudicá-los apenas em relação ao que praticantes de grandes roubos tinham a esconder da Polícia, esquecendo-me dos segredos que envolvem suas relações conjugais e amorosas (uma dimensão etnograficamente percebida como central em suas vidas) acabei apreendendo-os por uma perspectiva identificada com regimes morais, legais e intelectuais dominantes. Não ter lembrado que suas companheiras também poderiam puni-los por transgressões às normas morais que prescrevem os comportamentos dos participantes de uma relação amorosa contradiz a abordagem empreendida no trabalho e a postura que adotei em campo. Afinal, o medo de serem descobertos em suas clandestinidades afetivas é uma das preocupações que movimentam o cotidiano destes homens. Esta decorrência do meu trabalho que fiz questão de expor, elucida que fazer da etnografia um "encontro" voltado a elaborar "ciência social do observado", embora seja uma busca recorrente entre os antropólogos, não é necessariamente alcançável em sua totalidade, existem armadilhas intelectuais e morais com desdobramentos epistemológicas que nos capturam, algumas vezes de maneiras tão sutis que podemos levar meses e anos para percebê-las. 


\section{Considerações Finais}

Já afirmou Geertz (1989), que a etnografia é um "risco elaborado para uma descrição densa" (Geertz, 1989: 16). Sem querer entrar na discussão sobre a definição de "descrição densa" e sua abrangência, tampouco se é o melhor caminho para a Antropologia, gostaria de explorar a ideia de "risco elaborado" e sua imbricação com a etnografia, esta experiência intelectual e humana das mais arriscadas. É exatamente nos riscos que reside sua riqueza. Nesta modalidade de encontro intercultural, uma parte dos riscos são calculados e refletidos, mesmo assim reina a imprevisibilidade.

Ao iniciar um trabalho de campo, o antropólogo não tem nenhuma garantia de que irá conseguir ser aceito pelo coletivo a ser pesquisado, se a ele será dada oportunidade de dialogar e observar, se irá conseguir respostas para suas perguntas a respeito do tema em estudo. Mas um trabalho de campo não fracassa quando não encontramos as respostas que procuramos, o fracasso reside em não mudarmos nossas perguntas, quando estas se mostram incompatíveis com o universo etnográfico. Quem não está disposto a mudar os rumos de sua pesquisa diante de descobertas ou imprevistos com os quais se depara, permanecendo preso a armaduras teóricas e noções prévias, não faz etnografia. Esta parece se desenrolar coma uma dança ritmada de passos imprevisíveis, exigindo conexão e sincronia entre campo e pesquisador. Qualquer etnografia, independente da temática, portanto, é perigosa, abundante em riscos epistemológicos, existenciais, interacionais, dentre outros. Além das modalidades de riscos mencionadas, a minha tese, inicialmente, parecia envolver também perigo físico, afinal praticantes de assaltos contra instituições financeiras empunham armas, proferem ameaças, chegam a agredir fisicamente e até a matar suas vítimas. Conseguir desenvolver diálogo e aproximação com estas pessoas, não só parecia envolver riscos a minha integridade física, mas também tinha chances de ser inexequível. Felizmente, etnografias reservam espaço para que o improvável ocorra.

Depois de realizadas algumas entrevistas, no interior de uma prisão de segurança máxima, com homens que tinham participado de assaltos contra bancos, carros fortes e empresas de guarda valores, os diálogos seguintes e a inserção no universo dos assaltos contra instituições financeiras, surpreendentemente fluíram. Sempre que reflito sobre o que motivou a receptividade daqueles homens em relação ao meu trabalho, concluo que influenciaram positivamente as informações de que eu dispunha e o entusiasmo que 
demonstrava ao falar do tema. Sabia sobre as diferentes etapas e formatos que podem assumir uma operação de assaltos contra instituições financeiras, os modelos mais recorrentes de abordagens de alvos e de fugas. Sabia nomes de dezenas de assaltantes, sobre as metodologias e formatos preferidos de empreender assaltos por alguns deles. Antes de ter contato direto com estes homens fiz uma vasta pesquisa hemerográfica sobre ocorrências de assaltos e prisões de assaltantes, realizei entrevistas com delegados de Polícia e policiais. Nas primeiras vezes em que consegui ficar frente a frente com praticantes de grandes roubos, costumava iniciar o diálogo demonstrando que tinha informações sobre os assaltos dos quais o entrevistado tinha participado, ao invés de ressaltar a dimensão criminosa e violenta destas ações, dava ênfase à criatividade manifestada pelos coletivos de assaltantes na elaboração dos planos ou originalidade nos formatos de abordagens dos alvos. Demonstrar interesse e conhecimento em relação às ocorrências nas quais se consideram "peritos" parecia ser um "bom caminho" para motivar os sujeitos da pesquisa a esboçarem narrativas e relatos sobre suas experiências e conhecimentos, e também para lhes conquistar a simpatia. Em poucos meses, havia se difundido entre dezenas praticantes de assaltos, atuantes em diferentes regiões do país, informações positivas sobre minha mim e a pesquisa que eu estava desenvolvendo. Conforme me contaram no decorrer do trabalho de campo, diziam uns aos outros que havia uma "doutorinha" 9 escrevendo um livro, que "a moça entendia muito de assalto" e que era "de confiança". Alguns dos homens que me concederam entrevistas no interior da prisão, posteriormente, colocaram-me em contato com outros praticantes de assaltos, entre estes havia os que estavam reclusos em outras unidades prisionais, os que usufruíam de liberdade condicional e os que se encontravam foragidos da Justiça. Embora tenha vivenciado dilemas éticos e dificuldades para operacionalizar a pesquisa, dada a necessidade de recorrentes viagens a diferentes regiões do país para encontrar interlocutores, acessar estas pessoas, acabou se mostrando mais fácil do que imaginei.

Conseguir contato direto, aproximação etnográfica e alguma confiança, embora tenha me assegurado informações, convívio, diálogos e até mesmo amizade com praticantes de assaltos contra instituições financeiras, não aniquilaram minhas incertezas e preocupações relacionadas à pesquisa. Na escrita do trabalho, além de esforço criativo direcionado à analise dos dados e à composição teórica da tese, foi necessário atenção e

\footnotetext{
${ }^{9}$ Muitos me chamavam de "doutorinha", não sei se esta denominação se deu porque algumas vezes os informei que estava cursando doutorado ou se associavam a minha imagem a dos seus advogados, a quem chamam de "doutor".
} 
cuidado incessantes para preservar o anonimato dos sujeitos da pesquisa. Em alguns trechos da tese, expor suas identidades correspondia à incriminá-los. Esta possibilidade me deixava receosa e, antecipadamente, sentia remorso. Nem mesmo a defesa da tese e o reconhecimento do trabalho, que este evento de diálogo e consagração acadêmica enseja, foram suficientes para eu considerar encerrada a experiência de contato intelectual e existencial com a temática dos grandes roubos e seus participantes. Conforme explicitei no primeiro tópico deste artigo, eu me sentia amedrontada em relação ao que poderia acontecer se agentes da Polícia ou operadores do direito viessem se sentir afrontados com minha pesquisa de campo e tentassem criminalizar meu empreendimento etnográfico. Havia ainda preocupações e expectativas relacionadas à recepção e avaliação da tese pelos meus interlocutores.

Embora tenha me empenhado em assegurar o anonimato das pessoas com quem desenvolvi diálogo e em não estigmatizar a condição de praticantes de assaltos contra instituições financeiras (procurei colocar em relevo também dimensões de suas trajetórias e rotinas que vão além da participação em atividades em atividades ilegais), mesmo assim os critérios de organização e exposição dos dados foram prioritariamente acadêmicos, não foi, nem deveria ser uma escrita "engajada", modelada para agradar meus interlocutores de campo, procurei me pautar por objetividade, imparcialidade e clareza, consistência empírica e teórica. Apesar de demonstrar profundo respeito e atenção ao universo e aos protagonistas dos grandes roubos, o trabalho também lhes direciona críticas, isto me fazia temer as leituras e impressões sobre a tese que teriam as pessoas com quem desenvolvi diálogo em campo. Fiquei apreensiva por vários meses, pois ter privilegiado a interlocução e os critérios de validação acadêmica de uma pesquisa não significava que eu não me preocupasse com o que iam pensar a respeito do trabalho os sujeitos de ação do meu objeto de estudo. Para quem pauta sua experiência etnográfica por simetria, informalidade e confiança mútua, ter uma recepção positiva do seu texto entre os interlocutores campo é tão relevante e compensador quanto a aprovação e as insígnias de importância acadêmica, concedidas pela banca examinadora ao trabalho.

Conforme enfatizei anteriormente, em vias de defender a tese meus maiores medos estavam relacionados à complicações com a Polícia e a Justiça, acreditava que o contato direto com pessoas que cometem crimes violentos e estavam em situação de ilegalidade poderia me levar a ser investigada e pressionada a delatar as pessoas com 
quem desenvolvi diálogo durante o trabalho de campo, o tempo e as circunstancias mostraram que estes receios, embora pertinentes, não se concretizaram. Olhando retrospectivamente para o trabalho de campo e sua escrita, percebo que os maiores perigos aos quais estava exposta eram de outra natureza: no tópico três deste texto, explico que posso vir a causar prejuízos diretos a alguns praticantes de assaltos, cujas vidas afetivas exponho detalhes. Caso suas companheiras venham ler meu livro, facilmente os enxergarão por trás dos nomes fictícios que os atribuo. Além disso, posso ter associado aos praticantes de assaltos uma imagem de "mulherengos" ou "galinhas". Embora sejam verdadeiras as informações apresentadas sobre os múltiplos compromissos afetivos mantidos em simultaneidade por um mesmo homem, fico incomodada ao supor que posso tê-los prejudicado em futuras conquistas amorosas. Argumento no item três que não ter atentado para esta possibilidade e ter centrado meus cuidados no risco do meu trabalho servir como prova contra alguma das pessoas com quem desenvolvi diálogo, de algum modo, elucida que considerei seus conflitos conjugais menos importantes do que as atividades criminais que desenvolvem, o que denunciaria uma visão sobre estas pessoas que prioriza ou as reduz a inserção no crime. Este, realmente, é um impasse em minha trajetória etnografando o universo dos grandes roubos e seus protagonistas que significo como insucesso ante uma armadilha epistemológica. Não vejo problema em admitir que sucumbi a alguns dos riscos, dentre tantos que espreitam o pesquisador em um empreendimento etnográfico. Assim como a experiência de viver, a de etnografar também é abundante em testes e incertezas.

Por meio da discussão metodológica que pretendi desenvolver neste artigo, quis mostrar que minha imersão no universo dos grandes roubos e o diálogo com seus protagonistas não terminou com a defesa da tese, tampouco os temores e incertezas aos quais eu me sentia exposta nas dimensões existencial, moral, jurídica e epistemológica desapareceram com a obtenção do título de doutora. Algumas inquietações, diálogos e vínculos de amizade construídos em campo transbordaram a duração do doutorado. Passados cinco anos da defesa da tese, avalio como singulares e estimulantes as impressões e leituras externadas pelos interlocutores de campo em relação ao meu texto. Além da tese pronta e de sua publicação em formato de livro, a etnografia em pauta me deixou como legado uma extraordinária experiência subjetiva e intelectual. Tive oportunidade de exercitar importantes descentramentos e relativizações, pude me perceber confiando, respeitando e "querendo bem" aos sujeitos da pesquisa, posturas 
que em outros contextos teriam sido bloqueadas por preconceitos e interdições de ordem moral e ética.

\section{Referências}

AQUINO, Jania P. D. Príncipes e Castelos de Areia: performance e liminaridade nos grandes roubos. Tese defendida no Programa de Pós-Graduação em Antropologia Social da Universidade de São Paulo, em agosto de 2009.

Príncipes e Castelos de Areia: um estudo da performance nos grandes roubos. São Paulo: Biblioteca 24 horas, 2010.

BARREIRA, César. Crimes por encomenda. Rio de Janeiro: Relume Dumará, 1998.

BIONDI, Karina. Junto e Misturado: uma etnografia do PCC. São Paulo: Terceiro Nome, 2010. CARDOSO DE OLIVEIRA, Roberto. "Aculturação e 'fricção interétnica'". América Latina, v. 6, n. 3, p. 33-46, 1963.

DAMATTA, Roberto. "Relativizando o Interpretativismo" In: CORRÊA, Mariza e LARAYA, Roque (orgs). Roberto Cardoso de Oliveira: Uma Homenagem. Campinas: Unicamp/ IFCH, 1992.

FAVRET-SAADA, Jeanne. "Ser afetado". Revista Cadernos de Campo. São Paulo, USP, 2005. GEERTZ, Cliford. Obras e vidas. O antropólogo como autor. Rio de Janeiro: Ed. da UFRJ, 2002.

A interpretação das culturas. Rio de Janeiro: LCT, 1989.

GOFFMAN, Alice. On the Run: fugitive life in an american city. Chicago: University of Chicago Press, 2014

GOLDMAN, Marcio \& STOLZE, Tânia, L. "Como se faz um Grande Divisor?". In Marcio Goldman, Alguma Antropologia. Rio de Janeiro: Relume Dumará, 1999.

GRILLO, Carolina, C. Coisas da vida no crime: tráfico e roubo nas favelas cariocas. Tese defendida no Programa de Pós-Graduação de Sociologia e Antropologia da Universidade Federal do Rio de Janeiro, 2013.

LÉVI-STRAUSS, Antropologia estrutural, São Paulo: Cosac Naif, 2008.

MARQUES. Adalton, J. Crime e Proceder: um experimento antropológico. São Paulo: Alameda, 2015.

MARCUS, George. "O que (logo) depois do 'pós'", Revista de Antropologia, V. 37. São Paulo: USP, 1994.

RAFAEL, Antônio C. B. Um abraço para todos os amigos: algumas considerações sobre o tráfico de drogas no Rio de Janeiro. Rio de Janeiro: EDUFF, 1998.

SILVA, Vagner Gonçalves da. "Entre a poesia e o Raio-x: a tendência pós-moderna na antropologia" (p.145-158); In: GUINSBURG, J.; BARBOSA, Ana Mae (org.). O PósModernismo. São Paulo: Perspectiva, 2005.

STRATHERN, Marilyn. "The Limits of Auto-Anthropology" in Anthony Jackson, (org.), Anthropology at Home. London, Tavistock, 1987.

ZALUAR, Alba. A Máquina e a Revolta. São Paulo: Brasiliense, 1985.

"A Aventura Etnográfica: atravessando barreiras, driblando mentiras". In: Adorno

S.(org.) As Ciências Sociais entre a Modernidade e a Contemporaneidade. Cadernos de Sociologia. Porto Alegre: PPGS, UFRGS, 1995.

WAGNER, Roy. A Invenção da Cultura. São Paulo: Cosac Naif, 2011.

Recebido em: 17/03/2015

Aprovado em: 10/06/2015 